\title{
A complete catalogue of algal taxa described by Pierre Compère
}

\author{
Ann Bogaerts ${ }^{1, *}$, Myriam de Haan ${ }^{1}$, Bart Van de Vijver ${ }^{1,2}$ \& Christine Cocquyt $^{1}$
}

${ }^{1}$ Botanic Garden Meise, Nieuwelaan 38, BE-1860 Meise, Belgium

${ }^{2}$ University of Antwerp, Department of Biology, ECOBE, Universiteitsplein 1, BE-2610 Wilrijk, Belgium

*Author for correspondence: ann.bogaerts@br.fgov.be

\begin{abstract}
Background - On the occasion of the $80^{\text {th }}$ anniversary of Pierre Compère, a catalogue of all algal and cyanobacterial taxa he described during his scientific career, was compiled.

Methods - This catalogue was assembled through consultation of Compère's numerous publications, database queries and contacts with different herbaria where his types are deposited.

Results - Pierre Compère described 123 new algal and cyanobacterial taxa. Most of the species belong to the Bacillariophyta, but he also published taxa in the Cyanobacteria, Chlorophyta, Chrysophyta and Euglenophyta. For each taxon, details on the location of the type specimens are included along with their sample localities, dates and references to the protologues. A selection of pictures and drawings are added to illustrate Pierre Compère's work. One name, Caloneis silicula f. angusta is being formally validated.
\end{abstract}

Key words - Algae, Bacillariophyta, Chlorophyta, Chrysophyta, Cyanobacteria, Euglenophyta, nomenclature, types, catalogue.

\section{INTRODUCTION}

Pierre Compère started his scientific career as botanist in 1959 mapping the vegetation of the Lower Congo in Central Africa. Due to political difficulties following the Congolese declaration of independence, he was forced to return to Belgium in 1960. Three years later, he started working as a phycologist at the National Botanic Garden of Belgium. His first algological publication discussed the Belgian Hautes Fagnes, but Africa always held his special interest. Especially the freshwater algae from Chad, Niger, Sudan, Libya, Zambia, Senegal, Egypt, Zaire (D.R.Congo) and Equatorial Guinea attracted his attention. Later in his career he also studied material from Asia and Oceania, including Iran, Cashmere and Papua New Guinea and more recently material from Brazil (Fabri \& Symoens 2000, Ector \& Hoffmann 2000, van Ee \& Cocquyt 2001). Although he did not visit most of these places himself, he studied material collected by other scientists including A. Iltis, P. Baert, J. Léonard, B. Van de Vijver, Th. Monod, H. Dumont, T. Lomema and R.D. Walmsley, resulting in the description of a large number of new taxa.

The present paper demonstrates the importance of Pierre Compère as one of the few phycologists worldwide who dealt with a broad variety of algal groups, including Cyanobacteria.

\section{MATERIAL AND METHODS}

The data for this catalogue was acquired in the first place by consulting all publications of Pierre Compère. Secondly, sev- eral databases such as BG-BASE which is the database used in the Botanic Garden Meise (Walter \& O'Neal 2007), Index Nominum Algarum (Silva 2014), Algaebase (Guiry \& Guiry 2014), AlgaTerra (Jahn \& Kusber 2014) and the Catalogue of Diatom Names (Fourtanier \& Kociolek 2011) were thoroughly searched. Finally the herbaria where the types were deposited have also been contacted.

The catalogue is composed as followed. The different algal phyla are ordered according to recent taxonomic insights starting with the Cyanobacteria, followed by the Euglenophyta, Bacillariophyta, Chrysophyta and Chlorophyta. Within each phylum genera and species names are listed in alphabetical order. Reference to the protologue for each taxon is given together with more detailed information on the type if available, such as where the types are housed, the name of the main collector and the collector number, date and locality of the sample. All publications by Compère were written in French or in English with one exception which was written entirely in Latin. In order to retain consistency, all information concerning the locality of the types written in French has been translated into English. Only the slides of the Bacillariophyta have been given a special BR code. The wet collections have a unique barcode which can be requested at the Botanic Garden Meise. In this case type and collector number are the same.

The holotypes of taxa for which $\mathrm{P}$. Compère featured as first author are in most cases deposited in the National Botanic Garden of Belgium (BR), currently the Botanic Garden Meise. Apart from the collection of Compère, the collections 
of J. Léonard, Onclin, Baert, Iltis, Walmsley and Monod also are deposited in BR. The isotypes and paratypes are dispersed throughout various other herbaria worldwide: Natural History Museum, London, UK (BM), Alfred-Wegener-Institut für Polar- und Meeresforschung, Bremerhaven, Germany (BRM), Muséum national d'Histoire naturelle, Paris, France (PC), Academy of Natural Sciences, Philadelphia, USA (PH), Harvard University, Farlow Reference Library and Herbarium of Cryptogamic Botany, Cambridge, USA (FH), Botanical Institute, Academy of Science of the Czech Republic, Třeboň, Museum of Natural History, Vienna, Austria (W), Laboratoire Géologique, Talence, France (TALE) and South African National Biodiversity Institute, Pretoria, South Africa (PRE). In the past isotypes also were deposited in the Van Heurck Herbarium (AWH) but although this herbarium is now permanently housed at the Botanic Garden Meise, it is still dealt with as a separate collection and the AWH numbering is kept. For taxa of which Pierre Compère was co-author, holotypes have been deposited in the associated herbarium of the first author such as the Université de Perpignan, France (USR 3278 CNRS-EPHE CRIOBE), Laboratoire d'Océanographie Biologique, Paris 6, France (LOB CNRS/UPMC), Ghent University, Belgium (GENT), Academy of Natural Sciences, Diatom Herbarium, Pennsylvania, USA (ANSP), California Academy of Sciences, USA (CAS), Eastern Michigan University, USA (EMC) and Universidade Federal do Paraná, Brazil (UPCB). According to the old accession list of $\mathrm{BR}$, the entire algal collection of J. Léonard was deposited in the herbarium of the National Botanic Garden of Belgium, but up to now we were unable to locate all of the material.

Diatoms, described in collaboration with Riaux-Gobin, have no light microscopic slides as holotype but are based on scanning electron microscopy (SEM). The number between brackets given after the figure number represents the number of the SEM stub. However, in some cases only the SEM micrograph of the diatom valve is mentioned and no stub number is available. Riaux-Gobin et al. (2010) always explained very well their point of view that it is impossible to preserve durable specimens on stubs used for SEM study.

The acronym of each herbarium, according to Index Herbariorum (Thiers 2014), is given for each type. Abbreviations of the authorities follow the International Plant Names Index (2012).

To illustrate Pierre Compère's work we added a few pictures. LM images were taken with an Olympus BX51 microscope equipped with differential interference contrast and digital UC30 camera, SEM images with a JEOL 5800 LV operating at $20 \mathrm{kV}$. Drawings were scanned with an EPSON $10000 \mathrm{XL}$.

\section{RESULTS}

Approximately 1,600 of Pierre Compère's algal specimens, comprising untreated material as well as microscopic permanent diatom slides, were deposited in the collection of the National Botanic Garden of Belgium (BR), currently housed at the Botanic Garden Meise.
A study of all his publications, as first or co-author, revealed that he described 123 algal taxa, including three new genera, 61 species, 43 forms, and sixteen varieties. Two genera belong to the Bacillariophyta, Nupela Vyverman \& Compère and Olifantiella Riaux-Gobin \& Compère, and one to the Chlorophyta, Bourrellyodesmus Compère. Most of the new taxa (including forms and varieties) belong to the Bacillariophyta (i.e. 59, belonging to 23 genera). But Pierre Compère also described several new taxa of Cyanobacteria (thirteen taxa distributed over nine genera), Chlorophyta (43 taxa distributed over twenty genera), Chrysophyta (one taxon) and Euglenophyta (four taxa distributed over three genera). One name, Caloneis silicula f. angusta has been formally validated.

\section{LIST OF ALGAL TAXA DESCRIBED BY P. COMPÈRE}

\section{Cyanobacteria}

Anabaena (Bory) Bornet \& Flahault

Anabaena leonardii Compère (fig. 1B)

Protologue - Compère 1967: 246, fig. 27.

Type - J. Léonard 3875bis (holo-).

Collector, number and date $-J$. Léonard 3875bis (29 Dec. 1964).

Locality - Chad, Ounianga Kébir, small salt lake near Lake of Katam, $19^{\circ} 04^{\prime} \mathrm{N} 20^{\circ} 30^{\prime} \mathrm{E}$.

Anabaena sphaerica Bornet \& Flahault var. ellipsoidea Compère

Protologue - Compère 1967: 247, fig. 28.

Type - J. Léonard 3806 (holo-).

Collector, number and date $-J$. Léonard 3806 (6 Dec. 1964).

Locality - Chad, Lake Chad, Chari Delta, $12^{\circ} 49^{\prime} \mathrm{N} 14^{\circ} 30^{\prime} \mathrm{E}$.

\section{Chroococcidiopsis Geitler}

Chroococcidiopsis bourrellyana Compère

Protologue - Compère 1998: 165, figs 1-11.

Type - P. Compère 4343 (holo-).

Collector, number and date $-P$. Compère 4343 (Nov. 1984).

Locality - Senegal, Fatich, river Siné, $14^{\circ} 20^{\prime} \mathrm{N} 16^{\circ} 23^{\prime} \mathrm{W}$.

Dichothrix (Zanardini) Bornet \& Flahault

Dichothrix elongata Compère

Protologue - Compère 1970: 56, figs 45-48.

Type-Monod 13772 (holo-).

Collector, number and date - Monod 13772 (24 Dec. 1966).

Locality - Chad, North Chad, massif of Ennedi, Aoué.

Fortiea G.De Toni

Fortiea africana Compère

Protologue - Compère 1967: 247, fig. 29.

Type - J. Léonard 3806 (holo-).

Collector, number and date $-J$. Léonard 3806 (6 Dec. 1964).

Locality - Chad, Lake Chad, Chari Delta, $12^{\circ} 49^{\prime} \mathrm{N} 14^{\circ} 30^{\prime} \mathrm{E}$. 


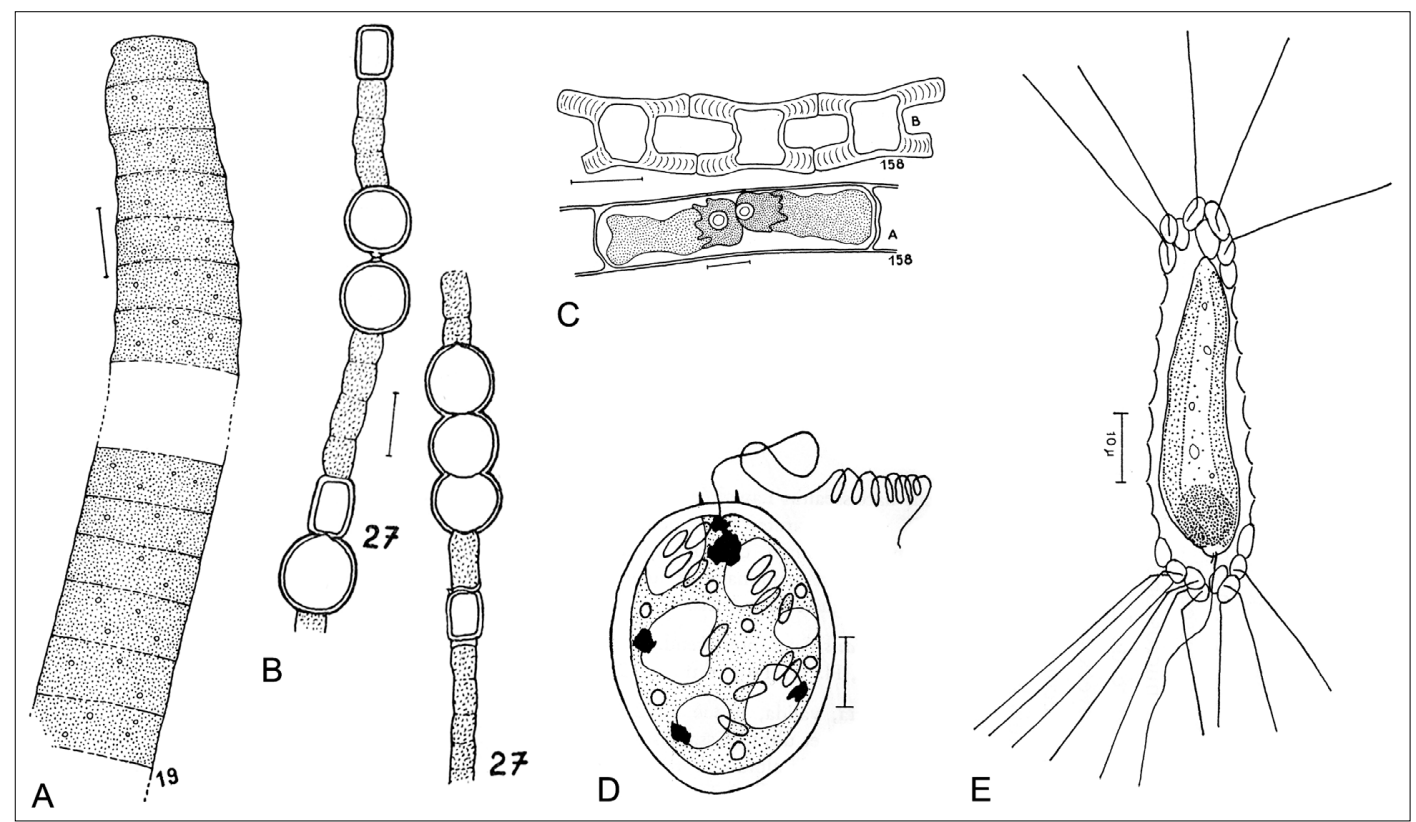

Figure 1 - Original drawings of P. Compère: A, Oscillatoria leonardii Compère (Compère 1967: pl. 1, fig. 19); B, Anabaena leonardii Compère (Compère 1967: pl. 2, fig. 27); C, Zygnemopsis densepunctata Compère (Compère 1967: pl. 11, fig. 158); D, Trachelomonas nigerica Compère (Compère 1975a: fig. 2); E, Mallomonas bronchartiana Compère (Compère 1974: fig. 1). Scale bars = $10 \mu \mathrm{m}$.

\section{Katagnymene Lemmerm.}

Katagnymene mucigera Compère, Komárek, Walmsley \& Barlow

Protologue - Compère et al. 1979: 387, figs 1 \& 8-17.

Type - Walmsley 78 LA (holo-); in PRE \& Třeboň (iso-); fig. 1 (icon).

Collector, number and date - Walmsley 78 LA (15 Nov. 1976).

Locality - South Africa, Transvaal Prov., Lindleyspoort reservoir.

Lyngbya C.Agardh ex Gomont

Lyngbya tchadensis Compère

Protologue - Compère 1974: 18, fig. 1.

Type - P. Compère 3880 (holo-).

Collector, number and date - P. Compère 3880 (Jan.-Mar. 1968).

Locality - Chad, Lake Chad, southeastern part, in front of the pass to Hadjer el Hamis, $12^{\circ} 57^{\prime} \mathrm{N} 14^{\circ} 41^{\prime} \mathrm{E}$.

\section{Oscillatoria (Vaucher) Gomont}

Oscillatoria chlorina Kütz. ex Gomont f. major Compère

Protologue - Compère 1967: 246, fig. 15.

Type - J. Léonard 3818 (holo-).

Collector, number and date $-J$. Léonard 3818 (24 Dec. 1964).

Locality - Chad, Ounianga Kébir, Lake Djobo, $19^{\circ} 04^{\prime} \mathrm{N}$ $20^{\circ} 30^{\prime} \mathrm{E}$.

Oscillatoria gerdae Compère

Protologue - Compère 1974: 20, fig. 3.

Type - P. Compère 3795 (holo-).

Collector, number and date - P. Compère 3795 (Jan.-Mar. 1968).
Locality - Chad, Lake Chad, Kare Katia, creek of the lake, $13^{\circ} 54^{\prime} \mathrm{N} 14^{\circ} 11^{\prime} \mathrm{E}$.

Oscillatoria iltisii Compère

Protologue-Compère 1974: 20, fig. 2.

Type - A. Iltis $\mathrm{P}$ (holo-).

Collector, number and date - A. Iltis $\mathrm{P}$ (Mar--Apr. 1967).

Locality - Niger, Lake Chad, northern part, bay south of Diakimé, $14^{\circ} 23^{\prime} \mathrm{N} 13^{\circ} 28^{\prime} \mathrm{E}$.

Oscillatoria leonardii Compère (fig. 1A)

Protologue - Compère 1967: 246, fig. 19.

Type - J. Léonard 3828 (holo-).

Collector, number and date $-J$. Léonard 3828 (5 Jan. 1965).

Locality - Libya, Oasis of Koufra, El Giof, Goudouie, $24^{\circ} 12^{\prime} \mathrm{N} 23^{\circ} 18^{\prime} \mathrm{E}$.

Plectonema (Thur.) Gomont

Plectonema monodii Compère

Protologue - Compère 1970: 57, figs 49-54.

Type-Monod 13879 (holo-).

Collector, number and date - Monod 13879 (11 Jan. 1967).

Locality - Chad, North Chad, massif of Ennedi, Ouro Gale.

Spirulina Turpin ex Gomont

Spirulina subsalsa Oerst. ex Gomont f. minor Compère

Protologue - Compère 1967: 246, fig. 25.

Type - J. Léonard 3827 (holo-).

Collector, number and date $-J$. Léonard 3827 (4 Jan. 1965).

Locality - Libya, Koufra Oasis, El Giof, Goudouie, $24^{\circ} 12^{\prime} \mathrm{N}$ $23^{\circ} 18^{\prime} \mathrm{E}$. 


\section{Euglenophyta}

Lepocinclis Perty

Lepocinclis senegalensis Compère

Protologue - Compère 1991: 192, fig. 69.

Type - P. Compère fig. 69 (icon).

Collector and date $-P$. Compère (Nov. 1984).

Locality - B11 - Senegal, Lake Guiers, Mbran, $16^{\circ} 02^{\prime} \mathrm{N}$

$15^{\circ} 56^{\prime} \mathrm{W} / \mathrm{B} 13$ - Senegal, Lake Guiers, Sier, $16^{\circ} 04^{\prime} \mathrm{N}$ $15^{\circ} 54^{\prime} \mathrm{W}$.

\section{Strombomonas Deflandre}

Strombomonas lagenaeformis Hub.-Pest. f. minor Compère Protologue - Compère 1991: 195, fig. 84.

Type - P. Compère 4311 (holo-); fig. 84 (icon).

Collector, number and date $-P$. Compère 4311 (Nov. 1984).

Locality - Senegal, Lake Guiers, $16^{\circ} 04^{\prime} \mathrm{N} 15^{\circ} 56^{\prime} \mathrm{W}$.

\section{Trachelomonas Ehrenb.}

Trachelomonas armata (Ehrenb.) F.Stein f. longicollis Compère

Protologue - Compère 1975a: 229, fig. 1.

Type - A. Iltis I (holo-).

Collector, number and date - A. Iltis I (Dec. 1965-Jan. 1966).

Locality - Chad, Chari Basin, Chari at N'Djamena (FortLamy), $12^{\circ} 07^{\prime} \mathrm{N} 15^{\circ} 02^{\prime} \mathrm{E}$.

Trachelomonas nigerica Compère (fig. 1D)

Protologue - Compère 1975a: 229-230, fig. 2.

Type - P. Compère 3917 (holo-).

Collector, number and date - P. Compère 3917 (Jan.-Mar. 1968).

Locality - Nigeria, Yobé Basin, Mamouri, delta river Yobé, $13^{\circ} 42^{\prime} \mathrm{N} 13^{\circ} 22^{\prime} \mathrm{E}$.

\section{Bacillariophyta}

\section{Achnanthes Bory}

Achnanthes exiguoides Compère

Protologue - Compère 1967: 247, fig. 55.

Type - Slide 905 in BR (holo-); slide 906 in BR (iso-).

Collector, number and date $-J$. Léonard 3853 (10 Dec. 1964).

Locality - Chad, Lake Chad, archipelago, c. $13^{\circ} 30^{\prime} \mathrm{N}$ $14^{\circ} 30^{\prime} \mathrm{E}$

\section{Achnanthidium Kütz.}

Achnanthidium flexuistriatum Riaux-Gob., Compère \& Witkowski

Protologue - Riaux-Gobin et al. 2010: 161, figs 13-22.

Type - SEM fig. 13 (140307-58) (holo-); slide 101388 in BM, slide ZU 6/80 in BRM, slide 4157 in BR, slide REU4 in USR 3278 CNRS-EPHE, CRIOBE (para-).

Collector, number and date $-C$. Riaux-Gobin 140307-58 (14 Jun. 2005).

Locality - Réunion, St. Leu South.
Achnanthidium glyphos Riaux-Gob., Compère \& Witkowski

Protologue - Riaux-Gobin et al. 2010: 161, figs 25-37.

Type - SEM fig. 27 (190706-1) (holo-); slide 101328 in BM, slide ZU 6/20 in BRM, slide 4108 in BR, slide REU1 in USR 3278 CNRS-EPHE, CRIOBE (para-).

Collector, number and date - C. Riaux-Gobin 190706-1 (Jun. 2005).

Locality - Réunion, 'Ferme corail 3'.

Achnanthidium pseudochamaepinnularia Riaux-Gob., Compère \& Witkowski

Protologue - Riaux-Gobin et al. 2010: 166, figs 38-47.

Type - SEM fig. 38 (070307-61) (holo-); slide 101389 in BM, slide ZU 6/81 in BRM, slide 4158 in BR, slide REU5 in USR 3278 CNRS-EPHE, CRIOBE (para-).

Collector, number and date - C. Riaux-Gobin 070307-61 (24 Jun. 2005).

Locality - Réunion, St. Leu city, lagoon beach, $21^{\circ} 09^{\prime} \mathrm{S}$ $55^{\circ} 18^{\prime}$ E, 'St. Leu U3'.

Achnanthidium pseudodelicatissimum Riaux-Gob., Compère \& Witkowski

Protologue - Riaux-Gobin et al. 2010: 159, figs 1-12.

Type - SEM fig. 1 (140307-65) (holo-); slide 101388 in BM, slide ZU 6/80 in BRM, slide 4157 in BR, slide REU4 in USR 3278 CNRS-EPHE, CRIOBE (para-).

Collector, number and date - C. Riaux-Gobin 140307-65 (14 Jun. 2005).

Locality - Réunion, St. Leu South.

Achnanthidium scalariforme Riaux-Gob., Compère \& Witkowski

Protologue - Riaux-Gobin et al. 2010: 170, figs 48-53.

Type - SEM fig. 50 (061206-53) (holo-); slide 101390 in BM, slide ZU 6/82 in BRM, slide 4159 in BR, slide REU6 in USR 3278 CNRS-EPHE, CRIOBE (para-).

Collector, number and date - C. Riaux-Gobin 061206-53 (Jun. 2005).

Locality - Réunion, 'Ferme corail 2'.

\section{Amphicocconeis M.De Stefano \& D.Marino}

Amphicocconeis mascarenica Riaux-Gob. \& Compère Protologue - Riaux-Gobin et al. 2011: 176, figs 1-5, 7-27 \& 39-41.

Type - SEM stub 'A24/01/2007' (holo-); SEM fig. 20 (240107-56) (icon); slide 101389 in BM, slide ZU 6/81 in BRM, slide 4158 in BR, slide REU5 in USR 3278 CNRSEPHE, CRIOBE (para-).

Collector, number and date - C. Riaux-Gobin A24/01/2007 (24 Jun. 2005).

Locality - Réunion, St. Leu city, lagoon beach, $21^{\circ} 09^{\prime} \mathrm{S}$ $55^{\circ} 18^{\prime}$ E, 'St. Leu U3'.

\section{Brachysira Kütz.}

Brachysira staurophora M.G.M.Souza \& Compère Protologue - Souza \& Compère 1999: 358, figs 1-6. Type - Sample 19133a in UPCB (holo-); slide A-GC 26798a in ANSP, slide 100169 in BM, slide ZU 4/95 in BRM, slide 4036 in BR (iso-). 
Collector and date - M.G.M de Souza (Mar. 1989-Mar. 1990).

Locality - Brazil, Federal District of Brazil, Lagoa Bonita, $15^{\circ} 34^{\prime} 45^{\prime \prime}$ S 4731'38'E.

\section{Caloneis Cleve}

Caloneis silicula (Ehrenb.) Cleve f. angusta Compère, nom. invalid.

Protologue - Compère 1967: 168, fig. 60.

Type - no Latin diagnosis, no indication of type.

Collector, number and date - Onclin in J. Léonard 3799

(Dec. 1964).

Locality - Algeria, Adrar, $27^{\circ} 50^{\prime} \mathrm{N} 0^{\circ} 10^{\prime} \mathrm{W}$.

Remark - as a Latin diagnosis and the indication of the type are lacking in the protologue, which were needed for a valid description in 1967, it is considered invalid according to the International Code of Nomenclature for algae, fungi, and plants (Art. $40 \& 44$, McNeill et al. 2012). In order to validate this taxon, a Latin description and a lectotype are provided here:

Caloneis silicula (Ehrenb.) Cleve f. angusta Compère ex Cocquyt \& Van de Vijver, f. nov.

Fig. 2

Differt a varietate nominata latitudine angustiori ornamentioneque valvae tenuiori. - Type: Algeria, Adrar, $27^{\circ} 50^{\prime} \mathrm{N}$ $0^{\circ} 10^{\prime} \mathrm{W}, 1964$, sample $J$. Léonard 3799 (lecto-: slide 1994 in $\mathrm{BR}$, designated here).

Remark - The valve representing the lectotype is here illustrated in fig. 2C.

\section{Cocconeis Ehrenb.}

Cocconeis alucitae Riaux-Gob. \& Compère

Protologue - Riaux-Gobin \& Compère 2008: 132, figs 2-15 \& 41-44.

Type - Slide REU1 in LOB CNRS/UPMC (holo-); slide 101328 in BM, slide ZU 6/20 in BRM, slide 4108 in BR (iso-).

Collector, number and date - C. Riaux-Gobin REU1 (Jun. 2005).

Locality - Réunion, 'Ferme Corail 3'.

Cocconeis borbonica Riaux-Gob. \& Compère

Protologue - Riaux-Gobin \& Compère 2008: 138, figs 24 $32 \& 45-47$.

Type - SEM fig. 24 (03306-29) (holo-); slide 101328 in BM, slide ZU 6/20 in BRM, slide 4108 in BR, slide REU1 in LOB CNRS/UPMC (para-).

Collector, number and date - C. Riaux-Gobin 03306-29 (Jun. 2005).

Locality - Réunion, 'Ferme Corail 3'.

Cocconeis coralliensis Riaux-Gob. \& Compère

Protologue - Riaux-Gobin \& Compère 2008: 135, figs 16$23 \& 52-55$.

Type - SEM fig. 16 (120705-28), original pict. in LOB CNRS/UPMC (holo-); slide 101329 in BM, slide ZU 6/21 in BRM, slide 4110 in BR, slide REU2 in LOB CNRS/UPMC (para-).
Collector, number and date - C. Riaux-Gobin 120705-28 (Jun. 2005).

Locality - Réunion, 'L'Hermitage $50 \mathrm{~cm}$ '.

Cocconeis mascarenica Riaux-Gob. \& Compère

Protologue - Riaux-Gobin \& Compère 2008: 140, figs 3340, 48-51.

Type - SEM fig. 33 (101106-7), original pict. in LOB CNRS/ UPMC (holo-); slide 101329 in BM, slide ZU 6/21 in BRM, slide 4110 in BR, slide REU2 in LOB CNRS/UPMC (para-). Collector, number and date - C. Riaux-Gobin 101106-7 (Jun. 2005).

Locality - Réunion, 'Ferme Corail 1'.

Cocconeis peltoides Hust. var. archaeana Riaux-Gob. \& Compère

Protologue - Riaux-Gobin et al. 2011: 330, figs 32-34.

Type - SEM fig. 25 (280207-47), original pict. in USR 3278 CNRS-EPHE, CRIOBE (holo-); slide 101389 in BM, slide ZU 6/81 in BRM, slide 4158 in BR, slide REU5 in USR 3278 CNRS-EPHE, CRIOBE (para-).

Collector, number and date - C. Riaux-Gobin 280207-47 (24 Jun. 2005).

Locality - Réunion, St. Leu city, lagoon beach, $21^{\circ} 09^{\prime} \mathrm{S}$ $55^{\circ} 18^{\prime} \mathrm{E}$, 'St. Leu U3'.

\section{Cymbella C.Agardh}

Cymbella hustedtii Krasske f. stigmata Compère

Protologue - Compère 1980: 291, figs 62, 86 \& 87.

Type - Slide 917 in BR (holo-); fig. 62 (icon); slide 918 up to 920 in BR (iso-).

Collector, number and date $-P$. Compère 4187 (Sep. 1977). Locality - Niger, Aïr Mountains, Tassenek, $18^{\circ} 32^{\prime} \mathrm{N} 8^{\circ} 45^{\prime} \mathrm{E}$.
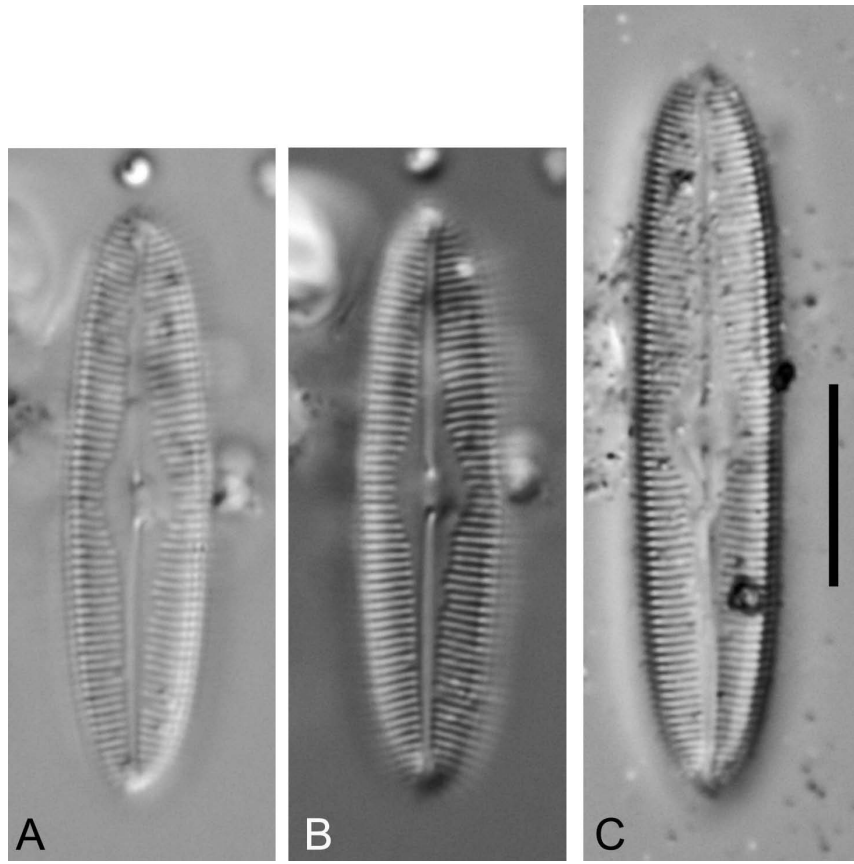

Figure 2 - Light micrographs of Caloneis silicula f. angusta. A-C, valves from sample $J$. Léonard 3799 (slide 1994 in BR); C, valve representing the lectotype. Scale bar $=10 \mu \mathrm{m}$. 
Cymbella oncliniorum Compère

Protologue - Compère 1967: 249, fig. 94.

Type - Slide 1166 in BR (holo-).

Collector, number and date - Onclin in J. Léonard 3795

(2 Dec. 1964).

Locality - Morocco, Oued Dra, $28^{\circ} 32^{\prime} \mathrm{N} 10^{\circ} 58^{\prime} \mathrm{W}$.

\section{Encyonopsis Krammer}

Encyonopsis horticola Van de Vijver \& Compère

Protologue - Van de Vijver et al. 2010: 199, figs 21-44.

Type - Slide 4165 in BR (holo-).

Collector and date - Van de Vijver B. (23 Jun. 2009).

Locality - Belgium, Meise, National Botanic Garden of Belgium, Herbarium Building, enclosed pond.

\section{Eunotia Ehrenb.}

Eunotia sennae M.G.M.Souza \& Compère

Protologue - Souza \& Compère 1999: 360, figs 7-12.

Type - Sample 19146 in UPCB (holo-); slide A-GC 26799 in ANSP, slide 100172 in BM, slide ZU 4/96 in BRM, slide 4037 in BR (iso-).

Collector and date - M.G.M de Souza (Mar. 1989-Mar. 1990).
Locality - Brazil, Federal District of Brazil, Lagoa Bonita, $15^{\circ} 34^{\prime} 45^{\prime \prime}$ S 4731'38”'E.

\section{Gomphonema Ehrenb.}

Gomphonema zairense Compère (fig. 3D)

Protologue - Compère 1995: 32, figs 1-14.

Type - Slide 1135 in BR (holo-); slides 1136 \& 1137 in BR, slide 82368 in BM, slide ZU 4/48 in BRM, slide 606368 in CAS, slide in AWH, slide in PC (iso-).

Collector, number and date $-J$. Léonard 1359 (30 Jun. 1947).

Locality - Zaire, Kisangani, Tshopo river waterfalls.

\section{Hantzschia Grunow}

Hantzschia distinctepunctata (Hust.) Hust. var. circuligera Compère

Protologue - Compère 1991: 218, figs 160-161.

Type - Slide 1127 in BR (holo-); slide 1128 in BR (iso-).

Collector, number and date - Compère 4337 (Nov. 1984).

Locality - Senegal, Senegal river, Saint-Louis, Langue de Barbarie, $16^{\circ} 00^{\prime} \mathrm{N} 16^{\circ} 31^{\prime} \mathrm{W}$.
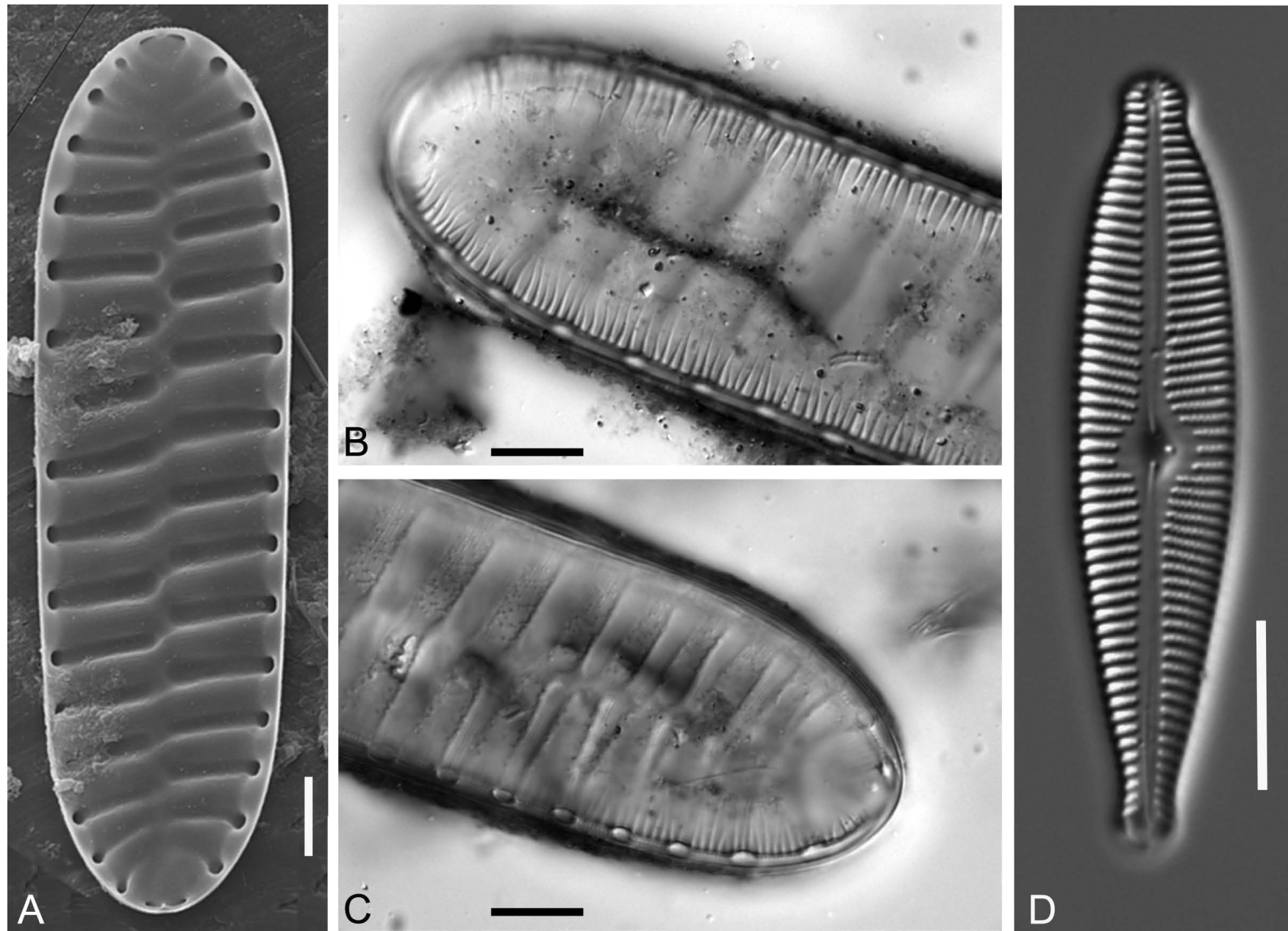

Figure 3 - A-C, Surirella murielae: A, scanning electron micrograph, internal valve view, from sample $P$. Compère 3875; B-C, light micrographs of valve from slide 984 in BR; D, Gomphonema zairense: light micrograph of valve from slide 1135 in BR. Scale bars $=10 \mu \mathrm{m}$. 
Kobayasiella Lange-Bert.

Kobayasiella mirabilis M.G.M.Souza \& Compère

Protologue - Souza \& Compère 1999: 362, figs 13-19.

Type - Sample 19133b in UPCB (holo-); slide A-GC 26798b in ANSP, slide 100170 in BM, slide ZU 4/97 in BRM, slide 4038 in BR (iso-).

Collector and date - M.G.M de Souza (Mar. 1989-Mar. 1990).

Locality - Brazil, Federal District of Brazil, Lagoa Bonita,

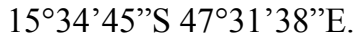

\section{Licmophora C.Agardh}

Licmophora gracilis (Ehrenb.) Grunow var. aegyptiaca Compère

Protologue - Compère 1994: 180, figs 27-31.

Type - Slide 1129 in BR (holo-); slide 1130 in BR (iso-).

Collector, number and date - P. Baert 2 (1989).

Locality - Egypt, Fayum, Qarum lake saline.

\section{Navicula Bory}

Navicula clementis Grunow f. major Compère

Protologue - Compère 1975b: 374, figs $1 \& 15$.

Type - Slide 938 in BR (holo-).

Collector, number and date - A. Iltis X (Jan.-Mar. 1968).

Locality - Chad, Lake Chad, southeastern part, Bol, $13^{\circ} 27^{\prime} \mathrm{N}$ $14^{\circ} 43^{\prime} \mathrm{E}$.

Navicula egregia Hust. f. elongata Compère

Protologue - Compère 1981: 21, fig. 56.

Type - J. Léonard 6239 fig. 56 (icon).

Collector, number and date - J. Léonard 6239 (1972).

Locality - Iran, Dasht-e-Lut, River Kal-Sur, after the plateau Gandum Bitiyan.

Navicula ennediensis Compère

Protologue - Compère 1970: 57, figs 86 \& 118 .

Type - Slide 2363 in BR (holo-).

Collector, number and date - Monod 13881 (Jan. 1967).

Locality - Chad, northern Chad, massif Ennedi, Ouri Gale.

Navicula leonardii Compère

Protologue - Compère 1967: 247, fig. 72.

Type - Slide 1978 in BR (holo-).

Collector, number and date $-J$. Léonard 3407 (3 Dec. 1964).

Locality - Cameroon, Tildé, El Béid, between Maltam and Waza, $12^{\circ} 08^{\prime} \mathrm{N} 14^{\circ} 44^{\prime} \mathrm{E}$.

Navicula mutica Kütz. f. densestriata Compère

Protologue - Compère 1967: 248, fig. 73.

Type - Slide 1973 in BR (holo-).

Collector, number and date - J. Léonard 3340bis (26 Dec. 1964).

Locality - Chad, Fort-Lamy, $12^{\circ} 08^{\prime} \mathrm{N} 15^{\circ} 02^{\prime} \mathrm{E}$.

Navicula pseudogrimmei Compère

Protologue - Compère 1970: 57, figs $87 \& 122$.

Type - Slide 940 in BR (holo-); slide 941 in BR (iso-).

Collector, number and date - Monod 13867 (9 Jan. 1967).

Locality - Chad, northern Chad, massif Ennedi, Diona.
Navicula pusilloides Compère

Protologue - Compère 1967: 248, fig. 74.

Type - Slide 942 in BR (holo-).

Collector, number and date $-J$. Léonard 3820 (25 Dec. 1964).

Locality - Chad, Ounianga Kébir, Lake Djobo, $19^{\circ} 04^{\prime} \mathrm{N}$ $20^{\circ} 30^{\prime} \mathrm{E}$.

Navicula scabellum Hust. f. major Compère

Protologue - Compère 1967: 248, fig. 75.

Type - J. Léonard 3830 (slides 2062 up to 2067 in BR were made from the holotype but not mentioned in the protologue).

Collector, number and date $-J$. Léonard 3830 (11 Jan. 1965)

Locality - Egypt, between Asyut and Qena, Nile valley, c. $26^{\circ} 05^{\prime} \mathrm{N} 32^{\circ} 30^{\prime} \mathrm{E}$.

Navicula silvatica Cholnoky f. acuta Compère

Protologue - Compère 1975b: 374, figs 2 \& 14.

Type - Slide 944 in BR (holo-).

Collector, number and date $-P$. Compère 3848 (Jan.-Mar. 1968).

Locality - Chad, Delta of Chari, northeastern branch of the delta, $12^{\circ} 54^{\prime} \mathrm{N} 14^{\circ} 33^{\prime} \mathrm{E}$.

Navicula subarvensis Hust. f. lata Compère

Protologue - Compère 1967: 248, fig. 77.

Type - Slide 2031 in BR (holo-).

Collector, number and date $-J$. Léonard 3819 (25 Dec. 1964).

Locality - Chad, Ounianga Kébir, Lake Yoan, $19^{\circ} 04^{\prime} \mathrm{N}$ $20^{\circ} 30^{\prime} \mathrm{E}$.

\section{Neidium Pfitzer}

Neidium grunowii Compère

Protologue - Compère 1975b: 376, figs 3 \& 21 .

Type - Slide 948 in BR (holo-); slide 949 in BR (iso-).

Collector, number and date $-P$. Compère 3816 (Jan.-Mar. 1968).

Locality - Chad, Lake Chad, southeastern part, Polder of Bol-Bérim, $3^{\text {rd }}$ barrier, $13^{\circ} 29^{\prime} \mathrm{N} 14^{\circ} 43^{\prime} \mathrm{E}$.

\section{Nitzschia Hassall}

Nitzschia curvata Compère

Protologue - Compère 1981: 25, figs 75 \& 124.

Type - J. Léonard 5830 fig. 75 (icon).

Collector, number and date - J. Léonard 5830 (1972).

Locality - Iran, depression of Jaz Murian, Magmadabad Zere Kalegang, $27^{\circ} 21^{\prime} \mathrm{N} 58^{\circ} 05^{\prime} \mathrm{E}$.

Nitzschia fonticola (Grunow) Grunow f. minutissima Compère

Protologue - Compère 1975b: 378, figs 5 \& 16 .

Type - Slide 950 in BR (holo-); slide 951 in BR (iso-).

Collector, number and date - P. Compère 3952 (Jan.-Mar. 1968).

Locality - Nigeria, Lake Chad, southern part, boundary southern free waters, north of Galoria, $12^{\circ} 35^{\prime} \mathrm{N} 13^{\circ} 55^{\prime} \mathrm{E}$. 
Nitzschia fragilariiformis Compère

Protologue - Compère 1986: 254, figs 1-16.

Type - Slide 952 in BR (holo-); slides 953 up to 956 in BR, slide 81194 in BM, slide ZU 2/98 in BRM, slide in AWH, slide in PC, slide in PH, slide in TALE, slide in W (iso-).

Collector, number and date - J. Léonard 4991 (1968).

Locality - Sudan, Jebel Unweinat, Karkur Murr.

Nitzschia iltisii Compère

Protologue - Compère 1975b: 379, figs $6 \& 24$.

Type - A. Iltis XII (holo-).

Collector, number and date $-A$. Iltis XII (Dec. 1965-Jan. 1966).

Locality - Chad, Lake Chad, Adjilélé.

Nitzschia iranica Compère

Protologue - Compère 1981: 27, figs 82 \& 129 .

Type - Slide 2169 in BR (holo-); fig. 82 (icon).

Collector, number and date - J. Léonard 5455 (1972).

Locality - Iran, Dasht-e-Kavir, surroundings of Tabas, $33^{\circ} 44^{\prime} \mathrm{N} 56^{\circ} 47^{\prime} \mathrm{E}$.

Nitzschia palea (Kütz.) W.Sm. f. minor Compère

Protologue - Compère 1967: 250, fig. 126.

Type - Slide 1995 in BR (holo-).

Collector, number and date - Onclin in J. Léonard 3800

(11 Dec. 1964).

Locality - Algeria, Salah, $27^{\circ} 12^{\prime} \mathrm{N} 2^{\circ} 28^{\prime} \mathrm{E}$.

Nitzschia serrata Manguin f. elongata Compère

Protologue - Compère 1975b: 379, figs $7 \& 22$.

Type - Slide 959 in BR (holo-).

Collector, number and date - A. Iltis I (Dec. 1965-Jan.

1966).

Locality - Chad, Chari Basin, in the Chari of N'Djamena (Fort-Lamy), $12^{\circ} 07^{\prime} \mathrm{N} 15^{\circ} 02^{\prime} \mathrm{E}$.

Nitzschia subrostrata Hust. f. elongata Compère

Protologue - Compère 1975b: 379, figs 8 \& 17 .

Type - Slide 960 in BR (holo-).

Collector, number and date - P. Compère 3857 (Jan.-Mar. 1968).

Locality - Cameroon, Delta of Chari, western branch of the delta, $12^{\circ} 53^{\prime} \mathrm{N} 14^{\circ} 28^{\prime} \mathrm{E}$.

Nitzschia subtilis Grunow f. tchadensis Compère

Protologue - Compère 1975b: 380, figs $9 \& 18$.

Type - P. Compère 3956 (slides 3269 up to 3271 in BR were made from the holotype sample but not mentioned in the protologue).

Collector, number and date - P. Compère 3956 (Jan.-Mar. 1968).

Locality - Nigeria, Lake Chad, southern part, bay of Wulgo, $12^{\circ} 32^{\prime} \mathrm{N} 14^{\circ} 10^{\prime} \mathrm{E}$.

Nitzschia tonoënsis Foged f. angustata Compère

Protologue - Compère 1975b: 380, figs $10 \& 25$.

Type - A. Iltis II (holo-).

Collector, number and date - A. Iltis II (Dec. 1965-Jan. 1966).

Locality - Cameroon, Chari Basin, in the Chari by Kousséri, $12^{\circ} 07^{\prime} \mathrm{N} 15^{\circ} 02^{\prime} \mathrm{E}$.
Nupela Vyverman \& Compère 1991a

Type species of the genus: Nupela giluwensis Vyverman \& Compère

Nupela giluwensis Vyverman \& Compère

Protologue - Vijverman \& Compère 1991a: 178, figs 1-10.

Type - PNG 435 in GENT (holo-).

Collector and date - W. Vyverman (Aug.-Oct. 1987).

Locality - Papua New Guinea, lake, Mt Giluwe, 603'08”S $143^{\circ} 55^{\prime} 40^{\prime \prime} \mathrm{E}$.

Olifantiella Riaux-Gob. \& Compère 2009

Type species of the genus: Olifantiella mascarenica RiauxGobin \& Compère

Olifantiella mascarenica Riaux-Gob. \& Compère

Protologue - Riaux-Gobin \& Compère 2009: 181, figs 1-5 \& 6-22.

Type - SEM fig. 8 (200208-61) (holo-); slide 101342 in BM, slide ZU 6/59 in BRM, slide 4133 in BR, slide REU3 in LOB CNRS/UPMC (para-).

Collector, number and date - C. Riaux-Gobin 200208-61 (14 Jun. 2007).

Locality - Réunion, 'Ferme Corail'.

\section{Pinnularia Ehrenb.}

Pinnularia dumontiorum Compère

Protologue - Compère 1980: 298, figs 102, 117 \& 118.

Type - P. Compère 4160 fig. 117 (icon).

Collector, number and date $-P$. Compère 4160 (Sep. 1977).

Locality - Niger, Mountains Bagzans, Canyon, Nabaru, $17^{\circ} 40^{\prime} \mathrm{N} 8^{\circ} 49^{\prime} \mathrm{E}$.

Pinnularia paulensis Grunow f. minor Compère

Protologue - Compère 1967: 248, fig. 83.

Type - Slide 1982 in BR (holo-).

Collector, number and date - J. Léonard 3550bis (13 Dec. 1964).

Locality - Chad, Lake Chad, zone of floating vegetation islands, c. $13^{\circ} 10^{\prime} \mathrm{N} 14^{\circ} 50^{\prime} \mathrm{E}$.

Pinnularia polyoncoides Compère

Protologue - Compère 1975b: 376, figs 4 \& 20.

Type - A. Iltis XII (holo-).

Collector, number and date $-A$. Iltis XII (Dec. 1965-Jan. 1966).

Locality - Chad, Lake Chad, Adjilélé.

Pinnularia sakulensis Vyverman \& Compère

Protologue - Vyverman \& Compère 1991b: 27, figs 1-9.

Type - PNG 4 in GENT (holo-).

Collector and date $-W$. Vyverman (Jul.-Sep. 1986).

Locality - Papua New Guinea, Sakula River, a small lowland river near Bogia on the North Coast, $4^{\circ} 14^{\prime} 06^{\prime \prime} S$ $144^{\circ} 53^{\prime} 40^{\prime \prime} \mathrm{E}$.

Pinnularia sulcata M.G.M.Souza \& Compère

Protologue - Souza \& Compère 1999: 362, figs 20-26.

Type - Sample 19133c in UPCB (holo-); slide A-GC 26798c in ANSP, slide 100171 in BM, slide 4039 in BR, slide ZU 4/98 in BRM (iso-). 
Collector and date - M.G.M de Souza (Mar. 1989-Mar. 1990).

Locality - Brazil, Federal District of Brazil, Lagoa Bonita, $15^{\circ} 34^{\prime} 45^{\prime \prime S} 47^{\circ} 31^{\prime} 38^{\prime \prime} \mathrm{E}$.

Pleurosira (Menegh.) Trevis.

Pleurosira laevis (Ehrenb.) Compère f. polymorpha Compère

Protologue - Compère 1982: 179, figs 18, 19, 26 \& 40.

Type - Slide 3228 (AWH V 27 A9) in BR (holo-); slide in BM, slide in BR, slide in PC (iso-); Van Heurck Synopsis Diat. Belg. Atlas, pl. 104, figs 3-4 (icon).

Collector and number - Van Heurck 496 (as Cerataulus laevis).

Locality - India.

Pleurosira socotrensis (Kitton) Compère var. bengalensis Compère

Protologue - Compère 1982: 183, figs 37, 38 \& 44.

Type - Slide 6079 in BM (holo-); slide 46204 in BM (iso-).

Collector - Dr Macrae.

Locality - India, Bengal, Salt Lake.

\section{Rhopalodia O.Müll.}

Rhopalodia tholulata Vyverman \& Compère

Protologue - Vyverman \& Compère 1991b: 28, figs 10-18.

Type - PNG 405 in GENT (holo-).

Collector and date - W. Vyverman (Jul.-Sep. 1986).

Locality - Papua New Guinea, Lake Sirunki, 525'21'S $143^{\circ} 31$ '50”'E.

\section{Stauroneis Ehrenb.}

Stauroneis abbottii Cholnoky \& G.G.Claus f. curta Compère

Protologue - Compère 1967: 249, fig. 86.

Type - J. Léonard 3820 (slides 2032 up to 2042 in BR were made from the holotype sample but not mentioned in the protologue).

Collector, number and date - J. Léonard $3820(25$ Dec. 1964).

Locality - Chad, Ounianga Kébir, Lake Yoan, $19^{\circ} 04^{\prime} \mathrm{N}$ 2030'E.

\section{Stauroneis leonardii Compère}

Protologue - Compère 1967: 249, fig. 87.

Type - Slide 981 in BR (holo-).

Collector, number and date $-J$. Léonard 3694 (29 Dec. 1964).

Locality - Chad, Ounianga Kébir, Lake Djobo, $19^{\circ} 04^{\prime} \mathrm{N}$ $20^{\circ} 30^{\prime} \mathrm{E}$.

\section{Stauroneis zairensis Compère}

Protologue - Compère et al. 1989: 224, figs 2-6 \& 8-13.

Type - Slide 1121 in BR (holo-); slide in AWH, slide 81537 in $\mathrm{BM}$, slide $\mathrm{ZU} 3 / 66$ in BRM, slide in PC, slide A-G.C. 17771 in PH (iso-); fig. 2 (icon).

Collector and date - T. Lomema (1987).

Locality - Zaire, Kinshasa, Funa Valley, fishpond in Monastery "Prière de Notre Dame de la Paix".

\section{Surirella Turpin}

Surirella linearis W.Sm. f. elongata Compère

Protologue - Compère 1975b: 380, figs 11 \& 23.

Type - Slide 982 in BR (holo-).

Collector, number and date - A. Iltis XII (Dec. 1965-Jan. 1966).

Locality - Chad, Lake Chad, Adjilélé.

Surirella murielae Compère (fig. 3A-C)

Protologue - Compère 1975b: 381, figs 12 \& 26.

Type - Slide 984 in BR (holo-).

Collector, number and date $-P$. Compère 3875 (Jan.-Mar. 1968).

Locality - Chad, Lake Chad, southeastern part, $10 \mathrm{~km}$ north of Chari Delta, $12^{\circ} 58^{\prime} \mathrm{N} 14^{\circ} 38^{\prime} \mathrm{E}$.

Surirella tchadensis Compère

Protologue - Compère 1975b: 381, figs 13 \& 19.

Type - Slide 987 in BR (holo-).

Collector, number and date $-P$. Compère 3880 (Jan.-Mar. 1968).

Locality - Chad, Lake Chad, southeastern part, in front of the pass to Hadjer el Hamis, $12^{\circ} 57^{\prime} \mathrm{N} 14^{\circ} 41^{\prime} \mathrm{E}$.

\section{Chrysophyta}

Mallomonas Perty

Mallomonas bronchartiana Compère (fig. 1E)

Protologue - Compère 1974: 61, figs 1-8.

Type - P. Compère 3833 (holo-).

Collector, number and date $-P$. Compère 3833 (Jan.-Mar. 1968).

Locality - Cameroon, Lake Chad, enclosed bay east of Meinari, $12^{\circ} 29^{\prime} \mathrm{N} 14^{\circ} 12^{\prime} \mathrm{E}$.

\section{Chlorophyta}

Arthrodesmus Ehrenb. ex Ralfs

Arthrodesmus bifidus Bréb. var. brevispinosus Compère

Protologue - Compère 1967: 250, fig. 162.

Type - J. Léonard 3407 (holo-).

Collector, number and date $-J$. Léonard 3407 (3 Dec. 1964).

Locality - Cameroon, Tildé, on El Béid, between Maltam and Waza, $12^{\circ} 08^{\prime} \mathrm{N} 14^{\circ} 44^{\prime} \mathrm{E}$.

\section{Bourrellyodesmus Compère 1977}

Type species of the genus: Bourrellyodesmus heimii (Bourr.) Compère

Bourrellyodesmus sumatranus C.E.M.Bicudo \& Compère Protologue - Bicudo \& Compère 1978: 419, fig. 10.

Type - M. Sachlan 149 in EMC (holo-); slide in FH (iso-); fig. 10 (icon).

Collector, number and date - M. Sachlan 149 (Dec. 1956). Locality - Indonesia, South of Palembang, Kaju-Agung, South Sumatra. 
Chlamydomonas Ehrenb.

Chlamydomonas reinhardtii P.A.Dang f. basimaculata Compère

Protologue - Compère 1980: 303, fig. 130.

Type - P. Compère 4153 (holo-); fig. 130 (icon).

Collector, number and date - $P$. Compère 4153 (Sep. 1977).

Locality - Niger, Aïr Mountains, Kori Tebagao, $17^{\circ} 20^{\prime} \mathrm{N}$ $8^{\circ} 15^{\prime} \mathrm{E}$.

\section{Closterium Ralfs}

Closterium kuetzingii Bréb. f. minus Compère

Protologue - Compère 1967: 251, fig. 165.

Type - J. Léonard 3807 (holo-).

Collector, number and date $-J$. Léonard 3807 (6 Dec. 1964).

Locality - Chad, Lake Chad, Chari Delta, $12^{\circ} 49^{\prime} \mathrm{N} 14^{\circ} 30^{\prime} \mathrm{E}$.

Closterium limneticum Lemmerm. f. elongatum Compère

Protologue - Compère 1976b: 457, fig. 1.

Type - P. Compère 3960 (holo-).

Collector, number and date - P. Compère 3960 (Jan.-Mar. 1968).

Locality - Cameroon, Lake Chad, southeastern part, floating vegetation islands near Hilé Alifa, $12^{\circ} 43^{\prime} \mathrm{N} 14^{\circ} 13^{\prime} \mathrm{E}$.

Closterium subulatum (Kütz.) Bréb. f. angustum Compère Protologue - Compère 1967: 251, fig. 169.

Type - J. Léonard 3812 (holo-).

Collector, number and date $-J$. Léonard 3812 (14 Dec. 1964).

Locality - Chad, Lake Chad, off Hadjer el Hamis, $12^{\circ} 51^{\prime} \mathrm{N}$ $14^{\circ} 51^{\prime} \mathrm{E}$.

\section{Coelastrum Nägeli}

Coelastrum reticulatum (P.A.Dang.) Senn f. duplex Compère

Protologue - Compère 1970: 57, fig. 178.

Type-Monod 13873 (holo-).

Collector, number and date - Monod 13873 (11 Jan. 1967). Locality - Chad, North Chad, massif Ennedi, Bimé, Enneri Michero.

\section{Cosmarium Ralfs}

Cosmarium beatum W.West \& G.S.West f. achondrum Compère

Protologue - Compère 1976b: 457, fig. 2.

Type - P. Compère 3878 (holo-).

Collector, number and date - P. Compère 3878 (Jan.-Mar. 1968).

Locality - Chad, Lake Chad, southeastern part, in front of the pass to Hadjer el Hamis, $12^{\circ} 57^{\prime} \mathrm{N} 14^{\circ} 41^{\prime} \mathrm{E}$.

Cosmarium bicorne Borge var. camerounense Compère Protologue - Compère 1976b: 458, fig. 3 .

Type - P. Compère 3837 (holo-).

Collector, number and date - P. Compère 3837 (Jan.-Mar. 1968).

Locality - Cameroon, El Béid Basin, Bodo, between Maltam and Fotokol, $12^{\circ} 21^{\prime} \mathrm{N} 14^{\circ} 28^{\prime} \mathrm{E}$.
Cosmarium clepsydra Nordst. var. tchadense Compère

Protologue - Compère 1976b: 458, fig. 4.

Type - P. Compère 3883 (holo-).

Collector, number and date - P. Compère 3883 (Jan.-Mar. 1968).

Locality - Chad, Lake Chad, southeastern part, south of the remarkable point, on the border of the floating vegetation islands, $13^{\circ} 01^{\prime} \mathrm{N} 14^{\circ} 43^{\prime} \mathrm{E}$.

Cosmarium cucumis Corda ex Ralfs f. maximum Compère Protologue - Compère 1976b: 459, fig. 5 .

Type - P. Compère 3807 (holo-).

Collector, number and date - P. Compère 3807 (Jan.-Mar. 1968).

Locality - Chad, Lake Chad, southeastern part, Bol, $13^{\circ} 27^{\prime} \mathrm{N}$ $14^{\circ} 43^{\prime} \mathrm{E}$.

Cosmarium furcatospermum W.West \& G.S. West var. bipyrenoidosum Compère

Protologue - Compère 1970: 58, figs 226 \& 227.

Type-Monod 13781 (holo-).

Collector, number and date - Monod 13781 (25 Dec. 1966).

Locality - Chad, North Chad, massif Ennedi, Koubé Basso.

Cosmarium gerdae Compère

Protologue - Compère 1976b: 459, fig. 6.

Type - P. Compère 3881 (holo-).

Collector, number and date - P. Compère 3881 (Jan.-Mar. 1968)

Locality - Chad, Lake Chad, southeastern part, south of the remarkable point, on the border of the floating vegetation islands, $13^{\circ} 01^{\prime} \mathrm{N} 14^{\circ} 43^{\prime} \mathrm{E}$.

Cosmarium incavatum W.B.Turner f. tchadense Compère Protologue - Compère 1976b: 460, fig. 7.

Type - P. Compère 3863 (holo-).

Collector, number and date - P. Compère 3863 (Jan.-Mar. 1968).

Locality - Chad, Chari Delta, northeastern branch of delta, $12^{\circ} 54^{\prime} \mathrm{N} 14^{\circ} 33^{\prime} \mathrm{E}$.

Cosmarium isthmochondrum Nordst. f. bipapillatum Compère

Protologue - Compère 1976b: 460, fig. 8.

Type - P. Compère 3957 (holo-).

Collector, number and date - P. Compère 3957 (Jan.-Mar. 1968).

Locality - Nigeria, Lake Chad, southern part, bay of Wulgo, $12^{\circ} 32^{\prime} \mathrm{N} 14^{\circ} 10^{\prime} \mathrm{E}$.

Cosmarium lamyfortanum Compère

Protologue - Compère 1976b: 460, fig. 9 .

Type - P. Compère 3762 (holo-).

Collector, number and date - P. Compère 3762 (Jan.-Mar. 1968).

Locality - Chad, Chari Basin, N'Djaména, road to Djermaya, $12^{\circ} 09^{\prime} \mathrm{N} 15^{\circ} 01^{\prime} \mathrm{E}$.

Cosmarium murielae Compère

Protologue - Compère 1976b: 462, fig. 10.

Type - P. Compère 3830 (holo-).

Collector, number and date - P. Compère 3830 (Jan.-Mar. 1968). 
Locality - Cameroon, El Béid Basin, closed bay east of Meinari, $12^{\circ} 29^{\prime} \mathrm{N} 14^{\circ} 12^{\prime} \mathrm{E}$.

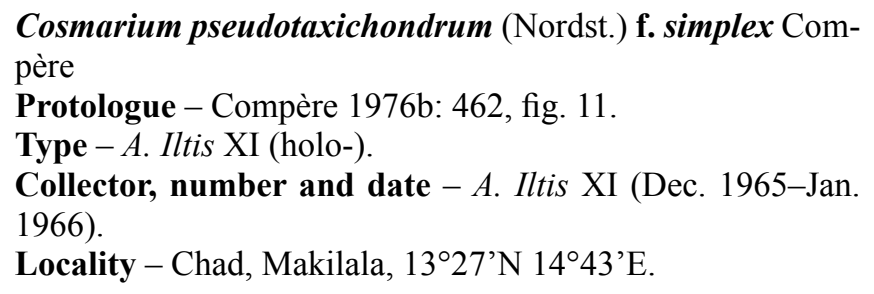

Cosmarium pseudotaxichondrum (Nordst.) f. simplex Compère

Protologue - Compère 1976b: 462, fig. 11.

Type - A. Iltis XI (holo-).

Collector, number and date - A. Iltis XI (Dec. 1965-Jan. 1966).

Locality - Chad, Makilala, $13^{\circ} 27^{\prime} \mathrm{N} 14^{\circ} 43^{\prime} \mathrm{E}$.

Cosmarium sinostegos Schaarschm. var. denticulatum Compère

Protologue - Compère 1976b: 464, fig. 12.

Type - P. Compère 3762 (holo-).

Collector, number and date - P. Compère 3762 (Jan.-Mar. 1968).

Locality - Chad, Chari Basin, N'Djaména, road to Djermaya, $12^{\circ} 09^{\prime} \mathrm{N} 15^{\circ} 01^{\prime} \mathrm{E}$.

Cosmarium venustum (Bréb.) W.Archer var. bimamillatum Compère

Protologue - Compère 1976b: 464, fig. 13.

Type - P. Compère 3837 (holo-).

Collector, number and date - P. Compère 3837 (Jan.-Mar. 1968).

Locality - Cameroon, El Béid Basin, Bodo, between Maltam and Fotokol, $12^{\circ} 21^{\prime} \mathrm{N} 14^{\circ} 28^{\prime} \mathrm{E}$.

\section{Euastrum (Ehrenb.) Ralfs}

Euastrum divergens Joshua var. bourrellyanum Compère

Protologue - Compère 1967: 251, fig. 201.

Type - J. Léonard 3407 (holo-).

Collector, number and date - J. Léonard 3407 (3 Dec. 1964).

Locality - Cameroon, Tildé, El Béid, between Maltam and Waza, $12^{\circ} 08^{\prime} \mathrm{N} 14^{\circ} 44^{\prime} \mathrm{E}$.

Euastrum glaziovii Børgesen f. simplex Compère

Protologue - Compère 1976b: 465, fig. 14.

Type - P. Compère 3797 (holo-).

Collector, number and date - P. Compère 3797 (Jan.-Mar. 1968).

Locality - Chad, Lake Chad, northern part, Kare Katia, creek of the lake, $13^{\circ} 54^{\prime} \mathrm{N} 14^{\circ} 11^{\prime} \mathrm{E}$.

Euastrum incertum F.E.Fritsch \& M.F.Rich f. minus Compère

Protologue - Compère 1967: 252, fig. 208.

Type - J. Léonard 3407 (holo-).

Collector, number and date - J. Léonard 3407 (3 Dec. 1964).

Locality - Cameroon, Tildé, El Béid, between Maltam and Waza, $12^{\circ} 08^{\prime} \mathrm{N} 14^{\circ} 44^{\prime} \mathrm{E}$.

Euastrum subhypochondrum F.E.Fritsch \& M.F.Rich var. croasdaleae Compère

Protologue - Compère 1976b: 465, fig. 15.

Type - P. Compère 3883 (holo-).

Collector, number and date $-P$. Compère 3883 (Jan.-Mar. 1968).
Locality - Chad, Lake Chad, southeastern part, south of the remarkable point, on the border of the floating vegetation islands, $13^{\circ} 01^{\prime} \mathrm{N} 14^{\circ} 43^{\prime} \mathrm{E}$.

\section{Gonatozygon de Bary}

Gonatozygon bourellyanum Compère

Protologue - Compère 1967: 250, fig. 163.

Type - J. Léonard 3812 (holo-).

Collector, number and date - J. Léonard 3812 (14 Dec. 1964).

Locality - Chad, Lake Chad, off Hadjer el Hamis, $12^{\circ} 51^{\prime} \mathrm{N}$ $14^{\circ} 51^{\prime} \mathrm{E}$.

Micrasterias C.Agardh ex Ralfs

Micrasterias radiosa Ralfs f. minuta Compère

Protologue - Compère 1967: 252, fig. 221.

Type - J. Léonard 3407 (holo-).

Collector, number and date $-J$. Léonard 3407 (3 Dec. 1964).

Locality - Cameroon, Tildé, El Béid, between Maltam and Waza, $12^{\circ} 08^{\prime} \mathrm{N} 14^{\circ} 44^{\prime} \mathrm{E}$.

\section{Mougeotia C.Agardh}

Mougeotia laetevirens (A.Braun) Wittr. f. tenuis Compère Protologue - Compère 1976a: 233, fig. 12.

Type - P. Compère 3846 (holo-).

Collector, number and date $-P$. Compère 3846 (Jan.-Mar. 1968).

Locality - Chad, Chari Basin, Douguia, $12^{\circ} 38^{\prime} \mathrm{N} 14^{\circ} 49^{\prime} \mathrm{E}$.

\section{Oedogonium Hirn}

Oedogonium demaretianum Compère

Protologue - Compère 1976a: 233, fig. 11.

Type - P. Compère 3856 (holo-).

Collector, number and date - P. Compère 3856 (Jan.-Mar. 1968).

Locality - Cameroon, Chari Delta, western delta branch, $12^{\circ} 53^{\prime} \mathrm{N} 14^{\circ} 28^{\prime} \mathrm{E}$.

\section{Pleurotaenium Nägeli}

Pleurotaenium elatum (W.Turner) Borge var. camerounense Compère

Protologue - Compère 1967: 252, fig. 225.

Type - J. Léonard 3407 (holo-).

Collector, number and date - J. Léonard 3407 (3 Dec. 1964).

Locality - Cameroon, Tildé, El Béid, between Maltam and Waza, $12^{\circ} 08^{\prime} \mathrm{N} 14^{\circ} 44^{\prime} \mathrm{E}$.

Provasoliella A.R.Loebl.

Provasoliella airensis Compère

Protologue - Compère 1980: 303, fig. 141.

Type - H. Dumont 126 E (holo-); fig. 141 (icon).

Collector, number and date $-H$. Dumont 126 E (Mar. 1977).

Locality - Niger, Aïr Mountains, Timia, $18^{\circ} 06^{\prime} \mathrm{N} 8^{\circ} 46^{`} \mathrm{E}$. 


\section{Scenedesmus Meyen}

Scenedesmus abundans (Kirchn.) E.Hegewald var. skujae Compère

Protologue - Compère 1970: 57, fig. 181.

Type-Monod 13881 (holo-).

Collector, number and date - Monod 13881 (Jan. 1967).

Locality - Chad, North Chad, massif Ennedi, Ouro Gale.

Scenedesmus dimorphus (Turpin) Kütz. var. longispina Compère

Protologue - Compère 1970: 58, fig. 192.

Type - Monod 13759 (holo-).

Collector, number and date - Monod 13759 (23 Dec. 1966).

Locality - Chad, North Chad, massif Ennedi, Negerba, temporary guelta west of Enneri Berdéché.

Scenedesmus perforatus Lemmerm. f. bicaudatus Compère Protologue - Compère 1976b: 232, fig. 10.

Type - P. Compère 3899 (holo-).

Collector, number and date - P. Compère 3899 (Jan.-Mar. 1968).

Locality - Chad, Lake Chad, northern part, floating vegetation islands of Fodia, at the beginning of the Great Barrier, $13^{\circ} 24^{\prime} \mathrm{N} 14^{\circ} 06^{\prime} \mathrm{E}$.

\section{Sphaeroplea C.Agardh}

Sphaeroplea tenuis Fritsch $\mathbf{f}$. corrugata Compère

Protologue - Compère 1980: 313, figs 184-186 \& 187-188.

Type - P. Compère 4187 (holo-); figs 184-186.

Collector, number and date - P. Compère 4187 (Sep. 1977).

Locality - Niger, Aïr Mountains, Tassenek, 18 $8^{\circ} 32^{\prime} \mathrm{N} 8^{\circ} 45^{\prime} \mathrm{E}$.

\section{Spirogyra Link}

Spirogyra chakiensis (Rao) Kolkw. \& Krieg. f. major Compère

Protologue - Compère 1967: 250, fig. 154.

Type - J. Léonard 3407 (holo-).

Collector, number and date - J. Léonard 3407 (3 Dec. 1964).

Locality - Cameroon, Tildé, El Béid, between Maltam and Waza, $12^{\circ} 08^{\prime} \mathrm{N} 14^{\circ} 44^{\prime} \mathrm{E}$.

Spirogyra globulispora Gauth.-Lièvre f. ellipsoidea Compère

Protologue - Compère 1970: 58, fig. 212.

Type-Monod 13754 (holo-).

Collector, number and date - Monod 13754 (21 Dec. 1966).

Locality - Chad, North Chad, massif of Ennedi, Archeï.

\section{Staurastrum Meyen ex Ralfs}

Staurastrum brachioprominens Børgesen f. elongatum Compère

Protologue - Compère 1967: 252, fig. 229.

Type - J. Léonard 3811 (holo-).

Collector, number and date - J. Léonard 3811 (10 Dec. 1964).

Locality - Chad, Lake Chad, archipel, c. $13^{\circ} 30^{\prime} \mathrm{N} 14^{\circ} 30^{\prime} \mathrm{E}$.
Staurastrum iltisii Compère

Protologue - Compère 1976b: 467, fig. 16.

Type - A. Iltis VI (holo-).

Collector, number and date - A. Iltis VI (Dec. 1965-Jan. 1966).

Locality - Chad, Lake Chad, southeastern part, Isle Tarara, $12^{\circ} 58^{\prime} \mathrm{N} 14^{\circ} 38^{\prime} \mathrm{E}$.

Staurastrum muticum Bréb. ex Ralfs f. punctatum Compère Protologue - Compère 1967: 252, fig. 239.

Type - J. Léonard 3407 (holo-).

Collector, number and date - J. Léonard 3407 (3 Dec. 1964).

Locality - Cameroon, Tildé, El Béid, between Maltam and Waza, $12^{\circ} 08^{\prime} \mathrm{N} 14^{\circ} 44^{\prime} \mathrm{E}$.

Staurastrum thomassonianum Compère

Protologue - Compère 1976b: 468, fig. 17.

Type - P. Compère 3799 (holo-).

Collector, number and date - P. Compère 3799 (Jan.-Mar. 1968).

Locality - Chad, Lake Chad, northern part, Kare Katia, creek of the lake, $13^{\circ} 54^{\prime} \mathrm{N} 14^{\circ} 11^{\prime} \mathrm{E}$.

\section{Staurodesmus Teiling}

Staurodesmus cuspidatus (Bréb.) Teiling f. granulatus Compère

Protologue - Compère 1967: 253, fig. 251.

Type - J. Léonard 3806 (holo-).

Collector, number and date - J. Léonard 3806 (6 Dec. 1964).

Locality - Chad, Lake Chad, Chari Delta, $12^{\circ} 49^{`} \mathrm{~N} 14^{\circ} 30^{\prime} \mathrm{E}$.

Zygnema C.Agardh

Zygnema airense Compère

Protologue - Compère 1980: 316, figs 198 \& 199.

Type-Dumont 147E (holo-); fig. 199 (icon).

Collector, number and date - Dumont 147E (Mar. 1977).

Locality - Niger, Aïr Mountain, Tegguidâmo, $19^{\circ} 07^{\prime} \mathrm{N}$ $8^{\circ} 25^{\prime} \mathrm{E}$

Zygnemopsis (Skuja) Transeau

Zygnemopsis densepunctata Compère (fig. 1C)

Protologue - Compère 1967: 250, fig. 158.

Type - J. Léonard 3828 (holo-).

Collector, number and date $-J$. Léonard 3828 (5 Jan. 1965).

Locality - Libya, Oasis of Koufra, El Giof, Goudouie, $24^{\circ} 12^{\prime} \mathrm{N} 23^{\circ} 18^{\prime} \mathrm{E}$.

\section{ACKNOWLEDGEMENTS}

We are grateful to the curators of the herbaria of $\mathrm{PH}, \mathrm{BM}$, PC, TAL, FH and $\mathrm{W}$ for their additional information concerning types. The authors thank Richard Shutt for entering the information on the African algal collection housed in BR in BG-BASE. 


\section{REFERENCES}

Bicudo C.E.M., Compère P. (1978) A taxonomic study of the desmid genus Bourrellyodesmus (Zygnemaphyceae). Bulletin du Jardin botanique national de Belgique 48: 409-426.

Compère P. (1967) Algues du Sahara et de la région du lac Tchad. Bulletin du Jardin botanique national de Belgique 37: 109-288. http://dx.doi.org/10.2307/3667692

Compère P. (1970) Contribution à l'étude des eaux douces de l'Ennedi: VI Algues. Bulletin de l'Institut Fondamental d'Afrique Noire XXXII sér. A: 18-64.

Compère P. (1974) Cyanophycées de la région du lac Tchad, taxons, combinaisons et noms nouveaux. Bulletin du Jardin botanique national de Belgique 44: 17-21. http://dx.doi. org/10.2307/3667424

Compère P. (1975a) De duabus novis Trachelomonadibus (Euglenophyceae) e vicinitate lacus Tchad (Africa centralis). Bulletin du Jardin botanique national de Belgique 45: 229-230. http:// dx.doi.org/10.2307/3667605

Compère P. (1975b) Diatomées de la région du lac Tchad, taxons combinaisons et noms nouveaux. Bulletin du Jardin botanique national de Belgique 45: 373-382. http://dx.doi. org/10.2307/3667489

Compère P. (1976a) Observations taxonomiques et nomenclaturales sur quelques algues vertes (Chlorophyta) de la région du lac Tchad (Afrique Centrale). Bulletin du Jardin botanique national de Belgique 46: 227-234. http://dx.doi.org/10.2307/3667416

Compère P. (1976b) Observations taxonomiques et nomenclaturales sur quelques Desmidiées (Chlorophycophyta) de la région du lac Tchad (Afrique centrale). Bulletin du Jardin botanique national de Belgique 46: 455-470. http://dx.doi. org/10.2307/3667729

Compère P. (1980) Algues de l'Aïr (Niger). Bulletin du Jardin botanique national de Belgique 50: 269-329. http://dx.doi. org/10.2307/3667831

Compère P. (1981) Algues des déserts d'Iran. Bulletin du Jardin botanique national de Belgique 51: 3-40. http://dx.doi. org/10.2307/3667734

Compère P. (1982) Taxonomic revision of the diatom genus Pleurosira (Eupodiscaceae). Bacillaria 5: 165-190.

Compère P. (1986) Nitzschia fragilariiformis a new species from NW Sudan forming ribbon-like colonies. In: Ricard M. (ed.) Proceedings of the Eight International Diatom Symposium 1984: 253-258. Königstein, Koeltz Scientific Books.

Compère P. (1991) Contribution à l'étude des algues du Sénégal 1. Algues du lac de Guiers et du Bas-Sénégal. Bulletin du Jardin botanique national de Belgique 61: 171-267. http://dx.doi. org/10.2307/3668149

Compère P. (1994) Diatoms from Hypersaline Inland Waters of Egypt. In: Kociolek J.P. (ed.) Proceedings of the Eleventh International Diatom Symposium 1990: 175-188. San Francisco, California Academy of Sciences.

Compère P. (1995) Gomphonema zairense sp. nov. from the Tshopo waterfalls (Kisangani, Zaire). Diatom Research 10: 31-37. http://dx.doi.org/10.1080/0269249X.1995.9705328

Compère P. (1998) Chroococcidiopsis bourrelyana nov. sp. (Cyanophyta, Xenococcaceae). Cryptogamie, Algologie 19: 161-168.

Compère P., Komárek J., Walmsley R.D., Barlow D.J. (1979) Katagnymene mucigera, a new planktonic blue-green alga from South Africa. Bulletin du Jardin botanique national de Belgique 49: 383-391. http://dx.doi.org/10.2307/3668091
Compère P., Lomema T., Omalokoho T. (1989) Stauroneis zairensis sp. nov. d'un étang de pisciculture à Kinshasa, Zaire. Diatom Research 4: 217-225. http://dx.doi.org/10.1080/026924 9X.1989.9705071

Ector L., Hoffmann L. (2000) Hommage à Pierre Compère à l'occasion de sa retraite. Cryptogamie, Algologie 21: 201-211. http:// dx.doi.org/10.1016/S0181-1568(01)80002-7

Fabri R., Symoens J.-J. (2000) Pierre Compère, de la carte de végétation du Bas-Congo au secrétariat du comité pour la nomenclature des algues. Systematics and Geography of Plants 70: 227-223.

Fourtanier E., Kociolek J.P. (2011) Catalogue of Diatom Names, California Academy of Sciences, On-line Version updated 19 Sep. 2011 [online]. Available from http://research.calacademy. org/research/diatoms/names/index.asp [accessed 15 Jan. 2014].

Guiry M.D., Guiry G.M. (2014) AlgaeBase. World-wide electronic publication, National University of Ireland, Galway [online]. Available from http://www.algaebase.org [accessed 15 Jan. 2014].

Jahn R., Kusber W.-H. (eds) (2014) AlgaTerra Information System. Botanic Garden and Botanical Museum Berlin-Dahlem, Freie Universität Berlin [online]. Available from http://www.algaterra.org [accessed 15 Jan. 2014].

McNeill J., Barrie F.R., Buck W.R., Demoulin V., Greuter W., Hawksworth D.L., Herendeen P.S., Knapp S., Marhold K., Prado J., Prud'homme Van Reine W.F., Smith G.F., Wiersema J.H., Turland N.J. (2012) International Code of Nomenclature for algae, fungi and plants (Melbourne Code). Regnum Vegetabile 154, International Association for Plant Taxonomy. Königstein, Koeltz Scientific Books.

Riaux-Gobin C., Compère P. (2008) New Cocconeis taxa from coral sands off Réunion Island (Western Indian Ocean). Diatom Research 23: 129-146. http://dx.doi.org/10.1080/026924 9X.2008.9705742

Riaux-Gobin C., Compère P. (2009) Olifantiella mascarenica gen. $\&$ sp. nov., a new genus of pennate diatom from Réunion Island, exhibiting a remarkable internal process. Phycological Research 57: 178-185. http://dx.doi.org/10.1111/j.14401835.2009.00537.x

Riaux-Gobin C., Compère P., Al-Handal A.Y. (2011) New Amphicocconeis species off Mascarenes (Western Indian Ocean) and related taxa. Diatom Research 26: 175-188. http://dx.doi.org/10 $.1080 / 0269249 X .2011 .597958$

Riaux-Gobin C., Witkowski A., Compère P. (2010) SEM survey and taxonomic position of small-sized Achnanthidium (Bacillariophyceae) from coral sands off Réunion Island (Western Indian Ocean). Vie et milieu 60: 157-172.

Silva P. (2014) Index Nominum Algarum. University Herbarium, University of California, Berkeley [online]. Available from http://ucjeps.berkeley.edu/CPD/ [accessed 15 Jan. 2014].

Souza M.G.M., Compère P. (1999) New diatoms species from the Federal District of Brazil. Diatom Research 14: 357-366. http:// dx.doi.org/10.1080/0269249X.1999.9705477

The International Plant Names Index (2012) The International Plant Names Index [online]. Available from http://www.ipni.org [accessed 24 Apr. 2014]

Thiers B. (continuously updated) Index Herbariorum: A global directory of public herbaria and associated staff. New York Botanical Garden's Virtual Herbarium [online]. Available from http://sweetgum.nybg.org/ih/ [accessed 15 Jan. 2014].

Van de Vijver B., Lange-Bertalot H., Compère P. (2010) Two new freshwater diatom species (Bacillariophyceae) from a small 
Pl. Ecol. Evol. 147 (3), 2014

pool in the National Botanic Garden of Belgium. Belgian Journal of Botany 142: 194-203.

van Ee G., Cocquyt C. (2001) Pierre Compère met pensioen. Diatomedelingen 25: 19-23.

Vijverman W., Compère P. (1991a) Nupela giluwensis gen. \& spec. nov. A new genus of naviculoid diatoms. Diatom Research 6: 175-179. http://dx.doi.org/10.1080/0269249X.1991.9705156

Vyverman W., Compère P. (1991b) Pinnularia sakulensis and Rhopalodia tholulata, two new diatoms (Bacillariophyta) from Papua New Guinea. Belgian Journal of Botany 124: 27-32.
Walter K.S.J., O’Neal M.J. (2007) BG-BASE, Botanic Gardens Database, version 6.8. [accessed 15 Jan. 2014].

Manuscript received 14 Mar. 2014; accepted in revised version 3 Jun. 2014.

Communicating Editor: Jérôme Degreef. 